\title{
Challenging "Migration Governance" in the Middle East and Turkey: Dynamic Power Relations, Contested Interventions, and Individual Strategies
}

Edited by: Amreesha Jagarnathsingh, Maissam Nimer

\section{Introduction}

This special issue aims to challenge the way in which migration is "governed" in the Middle East and Turkey. Migration governance entails the "norms and organisational structures which regulate and shape how states respond to international migration." The concept is generally employed normatively; it is believed to be inherently good and useful in enabling states to resolve migration "problems," related to refugee "crises" for example, in the most efficient way possible. ${ }^{2}$ Indeed, much practitioner and academic literature generally focuses on which characteristics constitute "good governance," "bad governance," or "good enough governance.", Good, or good enough governance would be a prerequisite for economic and political development, whereas bad governance practices (such as corruption, lack of transparency, or limited accountability, among others) would indicate a state's "lack of development." In fact, perceived bad governance in Middle Eastern countries and Turkey, similar to some other countries in the "Global South," would indicate "weakness" of states that are "unable" to impose their will to societies. ${ }^{6}$ For this reason, these states are subjected to stricter controls, more rigid interventions, and an explicit political reform agenda through which transnational actors generally from "developed" countries - can pass their normativities, with little regard to local contexts. These judgements contribute in concealing power dynamics that underlie the governance of migration. Furthermore, they fail to question who has the ultimate decision-making power and legitimacy to determine the ground rules of what constitutes good governance.

While the term "migration governance" can be used in a less-normative manner, to describe existing patterns of cooperation, ${ }^{7}$ it nonetheless presents several limitations. For example, relying on Westphalian notions on state sovereignty, the state is often analysed as a "unitary rational

\footnotetext{
${ }^{1}$ Alexander Betts, "Introduction: Global Migration Governance," in Alexander Betts (ed.) Global Migration Governance, Oxford, Oxford University Press, 2011.

${ }^{2}$ Antoine Pécoud, Depoliticising Migration. Global Governance and International Migration Narratives, Hampshire, Palgrave, 2015.

${ }^{3}$ Merilee Grindle, “Good Enough Governance Revisited," Development Policy Review, 2007, 25 (5), p. 553-574.

${ }^{4}$ Robert Klosowicz, "The Problem of Bad Governance as a Determinant of State Dysfunctionality in Sub-Saharan Africa", Politeja, 2018, Vol. 56, p. 9-22.

${ }^{5}$ The terms "Global South" and "Global North," are by no means static concepts confined by geographical space. Generally, "Global South" refers broadly to the "Third World" or "developing" regions of Latin America, Asia, and Africa, while the "Global North" includes "western" regions such as Europe and North America.

${ }^{6}$ Joel Migdal, Strong Societies and Weak States: State-Society Relations and State Capabilities in the Third World, Princeton: Princeton University Press, 1988.

${ }^{7}$ Alexander Betts, op.cit., 2011.
} 
actor with functioning policymaking and bureaucratic apparatuses, clearly defined national borders, and a coherent sense of national identity." ${ }^{8}$ In reality, however, whether in the Global South or North, rationality is rarely the only notion informing policy making: government tiers and political actors may adopt varying stances on migration governance, which more often comes down to an accumulation of ad hoc policies, that eventually may or may not accumulate into a coherent framework.

Moreover, the concept of migration governance oversees the fact that in many Middle Eastern contexts, notably following Palestinian, Iraqi, and Syrian displacement, states initially adopted a laissez-faire migration governance strategy: the "governance of no governance." Arguably, an absence of strategic decision-making could indicate a state's passivity, or even indifference, towards migratory phenomena - whereby it cannot be denied that, in reality, states in the region host millions of refugees, ${ }^{10}$ unlike many countries in the Global North. However, a lack of coherent migration governance strategies could also be analysed as a soft-power approach, as a means to implicitly serve political agendas - which can include a securitisation of migration policies, financial support, the externalisation of European borders, or accession to the European Union (EU).

Some scholars, however, have contested whether international migration can in fact be controlled, at all, ${ }^{11}$ or emphasise states' lack of power to implement migration policies. ${ }^{12}$ Others even point out the counterproductive effects of seemingly "tightened governance," ${ }^{13}$ which overlooks, for example, the fact that interrupting circulation flows rather increases the permanent settlement of foreigners. This "now or never" migration can capture individuals in their host

\footnotetext{
${ }^{8}$ Fiona Adamson and Gerasimos Tsourapas, "The Migration State in the Global South: Nationalizing, Developmental, and Neoliberal Models of Migration Management", International Migration Review, 2019; Kenneth Waltz, Theory of International Politics, Reading, MA, Addison-Webley, 1979, p. 111-14; James Hollifield, "The Emerging Migration State," International Migration Review, 2004, 38(3), p. 885-912.

${ }^{9}$ Compare Karim El Mufti, "Official response to the Syrian refugee crisis in Lebanon, the disastrous policy of no-policy," Civil Society Knowledge Centre, Beirut, Lebanon Support, 2014.

${ }^{10}$ In this special issue, we use the term "migrants" to indicate people who moved, whether voluntarily or not. We use the term "refugee," as well, whereby it should be noted that, in many cases, the individuals might not be formally recognised by the state as such. As Osseiran notes in this issue's Postface, "the figure of the refugee that emerges, is one close to that of the migrant labourer - both characterised by being permanently temporary, generally without recourse to any long-term status."

${ }^{11}$ Jagdish Bhagwati, "Borders Beyond Control," Foreign Affairs, Council on Foreign Relations, 2003, available at: https://www.foreignaffairs.com/articles/2003-01-01/borders-beyond-control [last accessed on 20 April 2020];

Stephen Castles, "Why Migration Policies Fail," Ethnic and Racial Studies, 2004, 27(2), p. 205-227; James

Hollifield, Philip Martin, Takeyuki Tsuda \& Wayne Cornelius (eds.), Controlling Immigration: A Global Perspective, Stanford, Stanford University Press, 2004.

12 James Hollifield, op.cit., 2004.

${ }^{13}$ Mathias Czaika and Mogens Hobolth. "Do Restrictive Asylum and Visa Policies Increase Irregular Migration into Europe?" European Union Politics, 2016, 17(3), p. 345-65; Douglas Massey and Karen Pren, "Unintended consequences of US immigration policy: Explaining the post-1965 surge from Latin America," Population and Development Review, 2012, 38(1), p.1-29.
} 
country, but, moreover, can push them into situations of irregularity. ${ }^{14}$ Increased restrictions in migration policies furthermore tend to overlook the de facto dependence on an informal labour sector, or the emergence of unofficial - if not criminal - broker mechanisms, which often engage migrants in exploitative structures. ${ }^{15}$ Academics, adopting a Marxist approach towards migration governance, highlight the fact that migration governance can feed into exploitation through processes of racialisation, labour subordination, class formation, and discourses on "illegal aliens," as will be argued by Souad Osseiran in the Postface of this issue.

Alternatively, the concept of "multi-level migration governance" challenges normative definitions of States as the main actors in migration governance and considers alternative approaches to state-society relations, ${ }^{17}$ as it entails a system of continuous negotiation, whereby governance authority is not only dispersed vertically among state actors in different governmental tiers, but also horizontally, across non-state actors, such as civil society, or security assemblages. ${ }^{18}$ Although this architecture indeed seems better fit in Middle Eastern and Turkish contexts, given that it captures hybrid forms of governance between state and non-state, or formal and informal actors, it should be noted that the different levels are by no means clearly definable, but rather indicate a complex migration regime. Importantly, multi-level migration governance nevertheless assumes a top-down approach, and appears to focus on formal initiatives over informal ones.

On the one hand, it can be argued that multi-level migration governance facilitates a fragmented governance framework, which arguably serves states' interests. ${ }^{19}$ On the other hand, whereas states are in charge of facilitating mechanisms through which refugees and migrants have access to territory and protection, states' actions are themselves, contingent on trends on 'imperial collapse and decolonisation; idealies of developmentalism; and the global rise of deregulation and commodification" 20 - and are therefore increasingly shaped by transnational actors (e.g. international donors). State power is then being progressively redeployed away from national entities to intra- and supranational ones.

\footnotetext{
${ }^{14}$ Hein de Haas, Stephen Castles and Mark Miller, The Age of Migration: International Population Movements in the Modern World, New York, The Guilford Press, 6th edition, 2020 [first published in 1993].

${ }^{15}$ Dennis Broeders and Godfried Engbersen, "The Fight Against Illegal Migration - Identification Policies and Immigrants' Counterstrategies," American Behavioral Scientist, 2007, Vol. 50 (12), p. 592-609; Mathias Czaika and Mogens Hobolth, op.cit., 2016; Lebanon Support, "Formal Informality, Brokering Mechanisms, and Illegality. The Impact of the Lebanese State's Policies on Syrian Refugees' Daily Lives," Civil Society Knowledge Centre, Beirut, Lebanon Support, 2016.

${ }^{16}$ Nicholas De Genova, Working the Boundaries: Race, Space, and "Illegality" in Mexican Chicago, Durham, NC, Duke University Press, 2005.

${ }^{17}$ Migdal, op.cit., 1988.

${ }^{18}$ Ian Bache and Matthew Flinders, "Themes and Issues in Multi-Level Governance," in Ian Bache and Matthew Flinders (eds.), Multi-level Governance, Oxford: Oxford University Press, 2005.

${ }^{19}$ Alexander Betts, op.cit., 2011.

${ }^{20}$ Fiona Adamson and Gerasimos Tsourapas, op.cit., 2019.
} 
Further, a variety of state and non-state actors receive monetary funding by international donors to provide services for refugees and migrants. In the associative sector, which provides services typically offered by states, this not only created a market economy, reinforcing dependency structures on international donors, ${ }^{21}$ but "trapped" civil society actors in implementing roles, as well. ${ }^{22}$ States, in that case, navigate between the anticipation of (or even dependence on) foreign funds, while trying to maintain their sovereignty. ${ }^{23}$ In turn, migrants become passive recipients of services that are envisaged for them, rather than actively being involved or represented in decision-making processes. Lastly, exceeding this neoliberal doxa, academics note migration governance also as "a means of forcibly constituting national populations in an attempt to create ethno-religious homogeneity,",

In an attempt to challenge how "governance" materialises in reality in the Middle East and Turkey, this issue goes beyond binary oppositions of "good" or "bad" governance in "weak" or "strong" states, but rather questions the mere perception of "crises" that need top-down management. The 10 papers included stem from a variety of disciplines, theoretical backgrounds, and research methods. The majority of papers revolve around the experiences of, or interventions targeting Syrians, who constitute the most recent and substantial group of displaced in the Middle East and Turkey. Some papers examine Palestinian or Kurdish migratory experiences, as well. The individual trajectories, as well as organisational interventions and responses, are analysed in geographical spaces of the Middle East (Lebanon, Jordan, Egypt), Turkey, as well as some European countries (including Denmark, Germany). Lastly, this issue also takes into account the experiences of other migrants, such as domestic and construction workers.

As will be argued below, all papers, both explicitly or implicitly, challenge the way in which migration is governed in the Middle East and Turkey. They explore how, at all levels, agency is articulated, shaped, and continuously adjusted in migration processes. In doing so, they bring to the forefront a rather complex, dynamic aspect of power relations and hierarchies between actors at various levels. As such, although the outline of this issue is organised through different levels of analysis (namely subnational, individual and national or supranational, respectively), it by no means intends to present them as distinguishable levels of migration governance. Instead, it

\footnotetext{
${ }^{21}$ Sbeih Sbeih,"Les projets collectifs de développement en Palestine : Diffusion de la vulgate néolibérale et normalisation de la domination," Civil Society Knowledge Centre, Beirut, Lebanon Support, 2018.

${ }^{22}$ Marie-Noëlle AbiYaghi, Léa Yammine and Amreesha Jagarnathsingh," Civil Society in Lebanon: The Implementation Trap," Civil Society Knowledge Centre, Beirut, Lebanon Support, 2019.

${ }^{23}$ Michel-Rolph Trouillot, "The anthropology of the state in the age of globalization." Current Anthropology, 2001, Vol. 42, p.125-138.

${ }^{24}$ Fiona Adamson and Gerasimos Tsourapas, op.cit., 2019; Heather Rae, State Identities and the Homogenisation of Peoples, Cambridge, Cambridge University Press, 2002; Darshan Vigneswaran, Territory, Migration and the Evolution of the International System, London: Palgrave Macmillan, 2013.
} 
seeks to explore the nature of interactions between the levels, and the way in which actors engage in networks of governance, as part of a complex reality.

\section{Rethinking Top-Down Humanitarianism: Roles and Constraints of Solidarity Networks and Local Level Interventions}

The first section of this issue challenges the top-down character of local level initiatives by humanitarian and faith-based actors, in their effort to "govern" migration. It explores how some initiatives, upon closer scrutiny, seem to perpetuate structural inequalities, thereby defeating their self-proclaimed purposes. Lewis Turner, for example, highlights how refugee men, particularly single men, do not seem to be the focus of most humanitarian organisations in Za'atari camp in Jordan. His paper explores humanitarian workers' understanding of Syrian men and masculinities as a "challenge," and argues that humanitarian actors' work can center around their own values and understandings of "vulnerability," rather than the priorities of refugees. In doing so, humanitarian interventions can perpetuate inequalities of power and social injustice.

Existing or emerging networks of solidarity, which often remain invisible and understudied, would present alternatives to humanitarianism. Going beyond the logic of victimisation prevalent in humanitarian interventionism, such (in)formal networks and shared social spaces ${ }^{25}$ in which migrants and refugees actively participate, generally provide for more horizontal relations of mutual support, and can play important roles in their integration into host societies. Towards this end, Michael Kaplan argues that shared modes of association, such as religion, can offer generative insight into processes of agency and emplacement among refugees, and can shape relationships, new forms of identities, and solidarities. As such, he steers away from victimising aid-provider and aid-receiver relationships, but emphasises these networks' fluctuating roles and responsibilities.

However, the role of religion or ethnicity as unifying factors should not, by any means, be glorified or idealised. By analysing the daily struggles, aspirations, and longings of Syrian Kurdish migrants in Turkey, Adnan Keği and Saygun Gökarıksel demonstrate how the formation of solidarity relations between internally displaced Turkish Kurds and recently arriving Syrian Kurds is not at all a straightforward process. In fact, it is a process full of tensions, dilemmas, and challenges, arising from social differences and hierarchies of class, gender, and ethnicity. In the same vein, Zeynep Şahin Mencütek highlights the shortcomings of interventions, even when local and refugee-led, as she explores the mechanisms and strategies used by Syrian faith-based

\footnotetext{
${ }^{25}$ Elena Fiddian-Qasmiyeh, "Refugee-refugee relations in contexts of overlapping displacement," website, International Journal of Urban and Regional Research, 2016, available at:

https://www.ijurr.org/spotlight-on/the-urban-refugee-crisis-reflections-on-cities-citizenship-and-the-displaced/refuge e-refugee-relations-in-contexts-of-overlapping-displacement/; Firat Genç, "Migration as a Site of Political Struggle. An Evaluation of the Istanbul Migrant Solidarity Network," Movements. Journal for Critical Migration and Border Regime Studies, 2017, Vol. 3(2), p.117-132.
} 
actors, and their interactions with Turkish authorities in order to "prevent violence." Her case study of Şanlıurfa, a Turkish border city, illustrates how Syrian faith-based actors, in their attempts to reduce tensions, can implicitly serve the Turkish state's priorities of controlling Syrian presence, rather than actively negotiate in setting priorities to advance Syrians' access to rights.

Nevertheless, although the papers in this section acknowledge the increased influence of non-state actors, none of the papers received analyse challenges experienced by activists, grassroot movements, institated resistances, and mobilisations - whether they are operating from their host country, home country, or in transnational dimensions between both. It would be interesting, in further research, to consider how these initiatives are rooted in society, how they relate with their "beneficiaries," and whether or not they manage to inform institutional or policy reform.

\section{Lives and Trajectories of Migrants: Negotiating, Subverting, or Resisting Restrictive Contexts}

The second section in this issue centers around the impact of restrictive migration "governance," policies, or a lack thereof, at the individual level. Using a variety of participatory research methods, the papers explore refugees' and migrants' everyday struggles and negotiations in settling in varying host countries, and place these in larger contexts of consecutive displacement, or "permanent temporariness."

Indeed, when analysing migration governance, it is essential to acknowledge migrants as autonomous individuals ${ }^{26}$ that have aspirations, needs, and desires, ${ }^{27}$ who, moreover, develop mechanisms to navigate or resist restrictive migration policies. Towards this end, the papers of Mette Edith Lundsfryd Stendevad and Ruba Totah present narratives of displaced Palestinian women from Syria (Lundsfryd Stendevad) and Syrian and Palestinian Syrian artists (Totah) who migrated across the Middle East and Europe in order to navigate structural discriminative settings in different national contexts. In this sense, Lundsfryd Stendevad and Totah, while highlighting migrants' continuous struggle to negotiate the right to belong in a host country, as well as the right to return to their home countries, are no exception. However, Lundsfryd

\footnotetext{
${ }^{26}$ Yann Moulier Boutang, "Europa, Autonomie der Migration, Biopolitik," in Marianne Pieper, Thomas Atzert, Serhat Karakayal1, and Vassilis Tsianos, Campus Verlag, Empire und die biopolitische Wende: Die internationale Diskussion im Anschluss an Hardt und Negri, 2006, p. 169-80; Dimitris Papadopoulos, Niamh Stephenson and Vassilis Tsianos, "Escape Routes: Control and Subversion in the Twenty-First Century", London; Ann Arbor, MI, Pluto Press, 2008; Sabine Hess, "Border Crossing as Act of Resistance: The Autonomy of Migration as Theoretical Intervention into Border Studies," in Martin Butler, Paul Mecheril, and Lea Brenningmeyer (eds.), Resistance: Subjects, Representations, Contexts, Bielefeld: Transcript Verlag, 2017, p. 87-100.

${ }^{27}$ Nicola Genova, "The Incorrigible Subject: The Autonomy of Migration and the US Immigration Stalemate," in Andreas Oberprantacher, Andrei Siclodi (eds.) Subjectivation in Political Theory and Contemporary Practices. Palgrave Macmillan, London, 2016.
} 
Stendevad reveals how such challenges can reverberate over multiple generations, and can be juxtaposed by intersecting challenges of being stateless, female, and refugee. Totah, instead, emphasises processes of "home-making," by illustrating how cultural institutions and relational dynamics come together and influence disentanglement processes from prior social networks and political understandings. As such, she underlines the significant role that subnational actors can play in shaping migrants' experiences.

At the same time, migrants' strategies and practices of negotiation and resistance may challenge established orders of knowledge, and clash with logistical rationalities of governance systems managing the terms and conditions for refugee inclusion into the host society. ${ }^{28}$ Towards this end, Jennifer Gordon, through a discussion with Alia Hindawi, an advocate for the rights of migrant and refugee workers in the Middle East, explores interactions between the kafala (migrant sponsorship) system, and formal and informal structures on the transnational, national, subnational, and individual level - in order to fully understand exploitative structures engaging migrant workers in Jordan. Importantly, Hindawi argues that allowing the civil society actors a bigger space to operate, as well as increasing accountability of international financial institutions and multinational firms, could contribute to counter the exploitation of migrants.

Lastly, the section shed light on the limited extent to which migration policies, as well as local level interventions, take into account diversity of individual motivations and trajectories within wider macro-social structures based on ideologies, religion, class, gender, or ethnicity. ${ }^{29}$ However, while the papers illustrate how migrants adjust their trajectories in order to "integrate" in host communities and how agency is produced, they merely hint at the existence or emergence of informal structures. Similarly, the (un)intended effects of broker mechanisms on the integration process, as well as a critical re-evaluation of the concept of "integration"deserves more attention in further research. In order to deconstruct victimising or criminalising narratives on migrants and refugees, it is worthwhile to further investigate how migrants and refugees construct their own narratives and forms of knowledge in new spaces.

\section{Navigating (Supra)National Agendas: Conflicting Priorities and Bargaining Power}

The third and last section of this issue provides insight into the significant role of transnational actors in shaping migration "governance." Scholars have emphasised the need to renounce general conceptions of the "migration state" which are predominantly suited to advanced liberal democracies, and urge to consider alternative forms of migration management regimes outside

\footnotetext{
${ }^{28}$ Moritz Altenried, Manuela Bojadžijev, Leif Höfler, Sandro Mezzadra and Mira Wallis, "Logistical Borderscapes: Politics and Mediation of Mobile Labor in Germany after the 'Summer of Migration'," South Atlantic Quarterly, 2018, Vol.117 (2), p. 291-312.

${ }^{29}$ Joey Ager, Faith, Secularism, and Humanitarian Engagement: Finding the Place of Religion in the Support of Displaced Communities, NY, Palgrave Macmillan, 2015.

${ }^{30}$ James Hollifield, op.cit., 2004.
} 
the Global North. ${ }^{31}$ As such, rather than feeding into "weak state" perspectives, in which states in the Global South would depend on supranational financial support from the Global North, the papers in this section, by Nefise Ela Gökalp Aras and Clothilde Facon, instead, illustrate governance modalities in which state and non-state actors can interact, thereby challenging normativities of migration governance and dominant assumptions on what constitutes a "weak" state. $^{32}$

Importantly, they emphasise the dynamic character of emerging power relations between subnational, national, and supranational institutions, that is contingent on changing contexts over time. Gökalp Aras sheds light on recent changes in Turkey's border governance, and highlights how non-state actors, such as (I)NGOs, have assumed changing roles in border management processes. Nonetheless, she questions to what extent non-state actors, mainly (I)NGOs, are given space to operate, as they are mainly delegated to deliver the "care" functions by implementing service provisions, while the state retains "control" functions of regulation. This illustrates how non-state actors have to navigate the limitations of freedom of association, and (shrinking) spaces for civil society.

In contrast, Clothilde Facon argues how states, in fact, can capitalise on the governance of refugee "crises," and gain bargaining power in negotiations with supranational actors. She highlights the change in these interactions, by analysing the refugee response in Lebanon in terms of reception, employment, education, and return. In doing so, her research challenges the traditional conception that "structural inequality inevitably underpins North-South relations," by demonstrating a multifaceted relationship between the state and the supranational agenda, revealing a complex interplay of gain and losses on both sides. In this case, evolving dynamic power relations emerge whereby states are able to challenge supranational agendas.

Whereas both papers shed light on ways through which policies adopted in the region have managed people on the move, little significance is paid to the extent to which they are in accordance with human rights. Moreover, the emergence of assemblages, and how these might be informed by clientelist practices - for example based on ethnic, primordial, sectarian, or other identities - remains unexamined.

\section{Localised Knowledge Production in the Global South: The Need for Grounded Analyses}

The cross-cutting theme in this special issue appears to be the emphasis on mechanisms through which (non-)state actors in the Middle East and Turkey challenge top-down migration governance strategies - be it humanitarian interventions, national state policies, or the

\footnotetext{
${ }^{31}$ Fiona Adamson and Gerasimos Tsourapas, op.cit., 2019.

32 Jamil Mouawad, and Hannes Baumann. "Wayn Al-Dawla?: Locating the Lebanese State in Social Theory." Arab Studies Journal, 2017. Vol.25 (1),2017, 66 - 90.
} 
supranational order. Importantly, the papers illustrate that in reality, networked modes of governance exist in which a pluriformity of actors interact, and continuously negotiate their roles in society. Hence, the issue calls for a broader, less normative, and bottom-up perspective on migration governance, in which the articulation of agency processes at all levels remains central.

Towards this end, the papers of Kaplan, Şahin Mencütek, and Keği and Gökarıksel highlight the role of solidarity networks in creating more equal support systems at the local level, and invite revisiting their challenges and constraints. Other papers, instead, focus on the individual strategies to navigate increasingly restrictive contexts (Lundsfryd Stendevad, Totah, Gordon), or illustrate how states interact and negotiate with supranational bodies (Facon, Gökalp Aras). These findings, at least to a certain extent, favour more grassroots, tailored, and locally grounded interventions over global initiatives, and invite to rethink "weak" state perspectives. This issue thus argues for a re-evaluation of migration governance strategies at the supranational level, with more careful attention to the national, local and individual levels and their caveats. This underlines the importance of local knowledge production in the Global South. In particular, knowledge produced using participatory research methods, could provide a space for the displaced to voice their experiences and priorities, and inform sound policy-making.

Indeed, currently, there are over 70 million forcibly displaced individuals world wide, of which $84 \%$ live in the Global South. ${ }^{33}$ The Middle East and Turkey are currently both the largest source and largest recipients of refugees globally. ${ }^{34}$ Yet, most migration theories and subsequent policies are almost exclusively derived from studies in "advanced," high-income countries in the Global North, with a favourable bias towards liberal democratic states. ${ }^{35}$ Thus, findings cannot be transferred to current realities in countries of the Global South. Some concepts have largely assumed migration from developing to developed countries, as is the case for push and pull factors, ${ }^{36}$ for facilitators and barriers of integration, or for theories about migration drivers whereby migration is explained by wage differentials. ${ }^{37}$ As such, in essence, they fail to shed light on the integration of migrants into "developing" countries, or South-to-South migration. ${ }^{38}$

\footnotetext{
${ }^{33}$ United Nations High Commissioner for Refugees, UNHCR Figures at a Glance, website, 19 June 2019, available at: https://www.unhcr.org/figures-at-a-glance.html [last accessed 20 March 2020].

${ }^{34}$ Forced Migration Review, "Displacement in the Middle East,” Website, Forced Migration Review, 2017, available at: https://www.fmreview.org/middle-east-cfa [last accessed 20 April 2020].

${ }^{35}$ Fiona Adamson and Gerasimos Tsourapas, op.cit., 2019.

${ }^{36}$ Guido Dorigo and Waldo Tobler, "Push-Pull Migration Laws," Annals of the Association of American Geographers, 1983, Vol. 73 (1), p. 1-11.

${ }^{37}$ In line with, following a neoclassical economic approach: Lewis Arthur, "Economic development with unlimited supplies of labor," The Manchester School of Economic and Social Studies, 1954, Vol. 22, p. 139-191; Gustav Ranis, and John Fei. "A theory of economic development," American Economic Review, 1961, Vol. 51, p. 533-565; John Harris, and Michael Todaro, "Migration, unemployment, and development: A two-sector analysis," American Economic Review, 1970, Vol. 60, p. 126-142.

38 Stephanie Nawyn, "New Directions for Research on Migration in the Global South," International Journal of Sociology, 2016, Vol. 46 (3), p. 163-168.
} 
Indeed, there are differences between the Global North and Global South that ought to be considered in terms of migration management, networks of governance, border enforcement, rights protection regime, level of formality-informality, and different histories of migration. ${ }^{39}$ As migrant and refugee realities are entangled with and reflect on the existing social, economic, and political transformations taking place in both receiving and sending countries, ${ }^{40}$ there is a need to place migrants in the larger context of life in the Middle East and Turkey. Yet, this region has only recently joined the multitude of empirical testing grounds for migration concepts and theories. Their input, too often, remains invisible in the global migration debates, public discourses, and academic literature. Although this topic in itself deserves a new discussion, this could be attributed to limited research funding and training in the region, and funding from abroad generally appears to be geared towards production of reports, rather than in-depth analyses and theory development. Therefore, this special issue is particularly invested in furthering efforts in localised knowledge production and providing an exchange platform for emerging researchers.

In this vein, in order to contribute to more nuanced conceptualisations of migration governance, and to bring theories in migration studies into dialogue with local contexts and South-South migration, Souad Osseiran's Postface paper outlines how the status of refugee is formulated due to different histories of migration and state formation in the Middle East and Turkey, and explores the ways in which migrants' and refugees' presence is portrayed as "permanently temporary." In the process, she ties the multiplicity of statuses developed for migrants, but more importantly, the conditions of presence for refugees, to the underlying labour market relations impacting Syrian refugee presence. Here, unpacking refugee incorporation into local economies as surplus labour serves to highlight the economic underpinnings of migration and asylum policies and politics. In light of this context, she argues that the Syrian refugee presence in countries across the Middle East and Turkey has been constituted as temporary, tying their position as a precarious and exploitable labour power.

This issue seeks to challenge migration governance as theorised in the Global North, by exploring the nature, roles, and limitations of actors involved, the top-down character of initiatives, underlying power dynamics, and agency produced at all levels, with particular attention to local contexts in the Middle East and Turkey. As such, the issue underlines the importance of contextualised knowledge-production, that is grounded in local contexts, with specific attention to bottom-up and grassroot initiatives.

\footnotetext{
${ }^{39}$ Stephanie Nawyn, op.cit., 2016.

${ }^{40}$ Stephen Castles, Derya Özkul, and Magdalena Arias Cubas (eds.) Social Transformation and Migration: National and Local Experiences in South Korea, Turkey, Mexico and Australia, London, Palgrave Macmillan UK, 2015.
} 


\section{Acknowledgements:}

We are grateful to all peer-reviewers for sharing their invaluable feedback to the papers in this special issue. We would also like to thank the contributors, for the pleasant collaboration over the past period. Furthermore, we are thankful for the Lebanon Support team and the Civil Society Review Editorial Board, for providing the opportunity to create this special issue, and for their patience and hard work. Lastly, we extend our thanks to Ford Foundation, for making this issue possible.

\section{Bibliography}

Marie-Noëlle Abi Yaghi, Léa Yammine and Amreesha Jagarnathsingh," Civil Society in Lebanon: The Implementation Trap," Civil Society Knowledge Centre, Beirut, Lebanon Support, 2019.

Fiona Adamson and Gerasimos Tsourapas, "The Migration State in the Global South: Nationalizing, Developmental, and Neoliberal Models of Migration Management", International Migration Review, 2019.

Joey Ager, Faith, Secularism, and Humanitarian Engagement: Finding the Place of Religion in the Support of Displaced Communities, NY, Palgrave Macmillan, 2015.

Moritz Altenried, Manuela Bojadžijev, Leif Höfler, Sandro Mezzadra and Mira Wallis, "Logistical Borderscapes: Politics and Mediation of Mobile Labor in Germany after the 'Summer of Migration',"South Atlantic Quarterly, 2018, Vol.117 (2), p. 291-312.

Lewis Arthur, "Economic development with unlimited supplies of labor," The Manchester School of Economic and Social Studies, 1954, Vol. 22, p. 139-191.

Ian Bache and Matthew Flinders, "Themes and Issues in Multi-Level Governance," in Ian Bache and Matthew Flinders (eds.), Multi-level Governance, Oxford: Oxford University Press, 2005.

Alexander Betts, "Introduction: Global Migration Governance," in Alexander Betts (ed.) Global Migration Governance, Oxford, Oxford University Press, 2011.

Jagdish Bhagwati, "Borders Beyond Control," Foreign Affairs, Council on Foreign Relations, 2003, available at: https://www.foreignaffairs.com/articles/2003-01-01/borders-beyond-control [last accessed on 20 April 2020].

Dennis Broeders and Godfried Engbersen, "The Fight Against Illegal Migration - Identification Policies and Immigrants' Counterstrategies," American Behavioral Scientist, 2007, Vol. 50 (12), p. 592-609.

Stephen Castles, "Why Migration Policies Fail," Ethnic and Racial Studies, 2004, 27(2), p. 205-227.

Stephen Castles, Derya Özkul, and Magdalena Arias Cubas (eds.) Social Transformation and Migration: National and Local Experiences in South Korea, Turkey, Mexico and Australia, London, Palgrave Macmillan UK, 2015.

Mathias Czaika and Mogens Hobolth. "Do Restrictive Asylum and Visa Policies Increase Irregular Migration into Europe?” European Union Politics, 2016, 17(3), p. 345-65. 
Nicholas De Genova, "The Incorrigible Subject: The Autonomy of Migration and the US Immigration Stalemate," in Andreas Oberprantacher, Andrei Siclodi (eds.) Subjectivation in Political Theory and Contemporary Practices. Palgrave Macmillan, London, 2016.

Nicholas De Genova, Working the Boundaries: Race, Space, and "Illegality" in Mexican Chicago, Durham, NC, Duke University Press, 2005.

Guido Dorigo and Waldo Tobler, "Push-Pull Migration Laws," Annals of the Association of American Geographers, 1983, Vol. 73 (1), p. 1-11.

Karim El Mufti, "Official response to the Syrian refugee crisis in Lebanon, the disastrous policy of no-policy," Civil Society Knowledge Centre, Beirut, Lebanon Support, 2014.

Elena Fiddian-Qasmiyeh, "Refugee-refugee relations in contexts of overlapping displacement," website, International Journal of Urban and Regional Research, 2016, available at: https://www.ijurr.org/spotlight-on/the-urban-refugee-crisis-reflections-on-cities-citizenship-and-t he-displaced/refugee-refugee-relations-in-contexts-of-overlapping-displacement/.

Forced Migration Review, "Displacement in the Middle East," Website, Forced Migration Review, 2017, available at: https://www.fmreview.org/middle-east-cfa [last accessed 20 April 2020].

Firat Genç, "Migration as a Site of Political Struggle. An Evaluation of the Istanbul Migrant Solidarity Network," Movements. Journal for Critical Migration and Border Regime Studies, 2017, Vol. 3(2), p.117-132.

Merilee Grindle, "Good Enough Governance Revisited," Development Policy Review, 2007, 25 (5), p. 553-574.

Hein de Haas, Stephen Castles and Mark Miller, The Age of Migration: International Population Movements in the Modern World, New York, The Guilford Press, 6th edition, 2020 [first published in 1993].

John Harris, and Michael Todaro, "Migration, unemployment, and development: A two-sector analysis," American Economic Review, 1970, Vol. 60, p. 126-142.

Sabine Hess, "Border Crossing as Act of Resistance: The Autonomy of Migration as Theoretical Intervention into Border Studies," in Martin Butler, Paul Mecheril, and Lea Brenningmeyer (eds.), Resistance: Subjects, Representations, Contexts, Bielefeld: Transcript Verlag, 2017, p. $87-100$.

James Hollifield, “The Emerging Migration State," International Migration Review, 2004, 38(3), p. 885-912.

James Hollifield, Philip Martin, Takeyuki Tsuda \& Wayne Cornelius (eds.), Controlling Immigration: A Global Perspective, Stanford, Stanford University Press, 2004.

Robert Klosowicz, "The Problem of Bad Governance as a Determinant of State Dysfunctionality in Sub-Saharan Africa", Politeja, 2018, Vol. 56, p. 9-22.

Lebanon Support, "Formal Informality, Brokering Mechanisms, and Illegality. The Impact of the Lebanese State's Policies on Syrian Refugees' Daily Lives," Civil Society Knowledge Centre, Beirut, Lebanon Support, 2016. 
Douglas Massey and Karen Pren, "Unintended consequences of US immigration policy: Explaining the post-1965 surge from Latin America," Population and Development Review, 2012, 38(1), p.1-29.

Jamil Mouawad, and Hannes Baumann "Wayn Al-Dawla?: Locating the Lebanese State in Social Theory." Arab Studies Journal, 2017. Vol. 25(1), 2017, p. 66 - 90.

Joel Migdal, Strong Societies and Weak States: State-Society Relations and State Capabilities in the Third World, Princeton: Princeton University Press, 1988).

Yann Moulier Boutang, "Europa, Autonomie der Migration, Biopolitik," in Marianne Pieper, Thomas Atzert, Serhat Karakayal1, and Vassilis Tsianos, Campus Verlag, Empire und die biopolitische Wende: Die internationale Diskussion im Anschluss an Hardt und Negri, 2006, p. 169-80.

Stephanie Nawyn, "New Directions for Research on Migration in the Global South," International Journal of Sociology, 2016, Vol. 46 (3), p. 163-168.

Dimitris Papadopoulos, Niamh Stephenson and Vassilis Tsianos, "Escape Routes: Control and Subversion in the Twenty-First Century", London; Ann Arbor, MI, Pluto Press, 2008.

Antoine Pécoud, Depoliticising Migration. Global Governance and International Migration Narratives, Hampshire, Palgrave, 2015.

Heather Rae, State Identities and the Homogenisation of Peoples, Cambridge, Cambridge University Press, 2002.

Gustav Ranis, and John Fei. "A theory of economic development," American Economic Review, 1961, Vol. 51, p. 533-565.

Sbeih Sbeih,"Les projets collectifs de développement en Palestine: Diffusion de la vulgate néolibérale et normalisation de la domination," Civil Society Knowledge Centre, Beirut, Lebanon Support, 2018.

Michel-Rolph Trouillot, "The anthropology of the state in the age of globalization." Current Anthropology, 2001, Vol. 42, p.125-138.

United Nations High Commissioner for Refugees, UNHCR Figures at a Glance, website, 19 June 2019, available at: https://www.unhcr.org/figures-at-a-glance.html [last accessed 20 March 2020].

Darshan Vigneswaran, Territory, Migration and the Evolution of the International System, London: Palgrave Macmillan, 2013.

Kenneth Waltz, Theory of International Politics, Reading, MA, Addison-Webley, 1979, p. 111-14. 